\title{
Soybean in different forms of processing in the feeding of crossbred cows on brachiaria grass pastures
}

\author{
Vinícius Raimundi Andrade ${ }^{1}$, Fernando de Paula Leonel${ }^{2}$, Severino Delmar Junqueira Villela1, \\ Juliana do Carmo Carvalho' ${ }^{2}$, Raphael Pavesi Araújo ${ }^{3}$, Jonas Marco de Carvalho², Henrique \\ Valentim Nunes Machado ${ }^{2}$, Joanis Tilemahos Zervoudakis ${ }^{4}$
}

\footnotetext{
${ }^{1}$ Universidade Federal dos Vales do Jequitinhonha e Mucuri, Departamento de Zootecnia, Diamantina, MG, Brasil.

2 Universidade Federal de São João del Rei, Departamento de Zootecnia, São João del Rei, MG, Brasil.

${ }^{3}$ Instituto Federal do Tocantins, Colinas do Tocantins, TO, Brasil.

${ }^{4}$ Universidade Federal de Mato Grosso, Faculdade de Agronomia, Medicina Veterinária e Zootecnia, Cuiabá, MT, Brasil.
}

\begin{abstract}
The objective was to evaluate intake and digestibility of nutrients, as well as milk production and composition of the milk from F1 Holstein $\times$ Gyr cows kept on pasture, supplemented with sugarcane and concentrate (28\% CP). Five cows with $150 \pm 14$ lactation days and average milk production of $7.1 \pm 2.1 \mathrm{~kg}$ /day were distributed in a $5 \times 5$ Latin square design. The treatments were: soybean meal-based concentrate; soy bean-based concentrate; ground soybean-based concentrate; roasted soybean-based concentrate; and ground, roasted soybean-based concentrate. Dry matter (DM), organic matter, crude protein (CP), neutral detergent fiber (NDF), total carbohydrates and total digestible nutrients intakes were not affected by the diet, but ether extract intake was higher for the animals fed soy bean-based diets than those fed soybean meal. The digestibility of DM, NDF and $\mathrm{CP}$ did not differ. The corrected milk yield differed between treatments; animals on the treatment with soy bean-based concentrate had the lowest production in relation to the others, which did not differ from each other. There was no difference between treatments for milk composition. Thus, soybean meal can be replaced by ground soy beans or roasted soy beans (ground or whole) in diets for low-yield cows reared on Brachiaria decumbens pastures with no harm to milk production or composition. Therefore, the use of these alternative raw materials is recommended whenever their inclusion represents lower feeding costs.
\end{abstract}

Key Words: alternative feeds, intake, milk composition, milk yield

\section{Introduction}

Tropical forages present low digestibility and reduced protein content to meet the requirements of lactating cows, and even in the growth season, they do not provide enough nutrients for high milk yields. Hence, supplementation is an efficient alternative to improve animal performance, but the type of supplementation must be chosen based on the time of the year, production level, costs, and available feeds.

Protein is a limiting ingredient in diets for ruminants, and protein sources are the most expensive ingredients in the formulation of diets and supplements for lactating cows, due to their elevated requirement and high cost of traditional sources such as soybean meal. As an alternative, the use of soybean has increased. Because of the elevated fat content of this ingredient, about $19 \%$ of ether extract, its use as

Received August 7, 2014 and accepted November 26, 2014

Corresponding author: fernandoleonel@ufsj.edu.br

http://dx.doi.org/10.1590/S1806-92902015000200001

Copyright (@) 2015 Sociedade Brasileira de Zootecnia. This is an Open Access article distributed under the terms of the Creative Commons Attribution Non-Commercial License, which permits unrestricted non-commercial use, distribution, and reproduction in any medium, provided the original work is properly cited. a component in cattle diets has spread quickly. Therefore, there are several forms of processing soy to include it as an ingredient in the cattle diets, e.g., soybean meal, ground raw soybean, roasted soy beans, and ground, roasted soybeans, which were all utilized in this experiment.

Replacing soybean meal by the whole grain may provide changes in the fat content and milk production, due to the higher concentration of fat contained in the feed that can alter the metabolism of carbohydrate, also bringing economical advantages, given its lower market price.

The objective of this study was to evaluate the effect of the different forms of soy processing on the intake and digestibility of nutrients, as well as production and composition of milk from crossbred (Holstein $\times$ Gyr) cows on brachiaria grass pastures.

\section{Material and Methods}

The experiment was conducted in the county of São João Del Rei (MG/Brazil), whose geographical coordinates are $21^{\circ} 08^{\prime} 00^{\prime \prime}$ South latitude, $44^{\circ} 15^{\prime} 40^{\prime \prime}$ West longitude, and $898 \mathrm{~m}$ altitude, from August to November 2009 , which corresponded to part of the dry period of the region in that year. 
The area is located in a region where a Cwa climate (Köppen standards) predominates with an annual rainfall of $1,468 \mathrm{~mm}$ and annual temperature of $20.1^{\circ} \mathrm{C}$.

An experimental area of one hectare of Brachiaria decumbens pasture provided with masonry drinker with continuous water flow and trough for mineral supply was used.

The experiment consisted of five 14-day experimental periods each. The first nine days of the periods corresponded to the phase of acclimation, and the subsequent five days were used for sample and data collections.

The experimental design adopted was a $5 \times 5$ Latin square, consisting of five animals, five treatments and five experimental periods. The experimental treatments were: soybean meal-based concentrate $(\mathrm{SM})$; whole raw soybean-based concentrate (SB); ground soybean-based concentrate (GSB); roasted soybean-based concentrate (RSB); and ground, roasted soybean-based concentrate (GRSB). Roasting was performed at a temperature of $100{ }^{\circ} \mathrm{C}$ for one hour.

Five multiparous cows (Holstein $\times$ Gyr) in lactation, with an average live weight of $499 \pm 32 \mathrm{~kg}$, lactating period of $150 \pm 14$ days, and average production of $7.1 \pm 2.1 \mathrm{~kg}$ were used. These cows remained on pasture (Table 3) during the entire experimental period, under continuous grazing, and after milking sessions, which occurred at $06.30 \mathrm{~h}$ and $15.30 \mathrm{~h}$, they received the respective concentrates in individual troughs (Tables 1 and 2) at the ratio of $1 \mathrm{~kg}$ for every $3 \mathrm{~L}$ of milk produced. After the morning milking, only concentrate was supplied, and after the afternoon milking, the concentrate was provided with $5 \mathrm{~kg}$ of supplemental roughage (fresh, chopped sugarcane). The sugarcane was used so as to prevent overgrazing in the grazing area, in addition to simulating a common situation of dairy properties, which is the supply of sugarcane in the dry period for low-yield animals grazing on a lowquality pasture.

The diets were formulated according to the production requirements of the animals and in accordance with the recommendations of the NRC (2001); the level of $28 \%$ of crude protein $(\mathrm{CP})$ on a dry matter basis was established for the concentrates. For the collection of the pasture samples, the simulated-grazing method proposed by Sollenbergger and Cherney (1995) was adopted. According to those authors, this would be the best way of performing collection as close as possible to the feed the animals would be consuming. The samples were collected by the hand-plucking method, in which the forage is collected manually after previous observation of the grazing habit of the animals.

Table 1 - Proportion of ingredients utilized in the experimental concentrates, expressed on a fresh-matter basis

\begin{tabular}{|c|c|c|c|c|c|}
\hline \multirow{2}{*}{ Ingredient $(\mathrm{g} / \mathrm{kg})$} & \multicolumn{5}{|c|}{ Concentrate } \\
\hline & SM & SB & GSB & RSB & GRSB \\
\hline Corn & 414.3 & 314.3 & 314.3 & 314.3 & 314.3 \\
\hline Soybean meal & 557.1 & & & & \\
\hline Raw soybeans & & 657.1 & & & \\
\hline Roasted soybeans & & & & 657.1 & \\
\hline Ground raw soybeans & & & 657.1 & & \\
\hline Ground roasted soybeans & & & & & 657.1 \\
\hline Mineral & 28.6 & 28.6 & 28.6 & 28.6 & 28.6 \\
\hline
\end{tabular}

SM - soybean meal-based concentrate; SB - raw soybean-based concentrate; GSB - ground soybean-based concentrate; RSB - roasted soybean-based concentrate; GRSB - ground, roasted soybean-based concentrate.

Table 2 - Chemical composition $(\mathrm{g} / \mathrm{kg})$ of the concentrates utilized in the experimental diets and sugarcane, on a dry matter basis

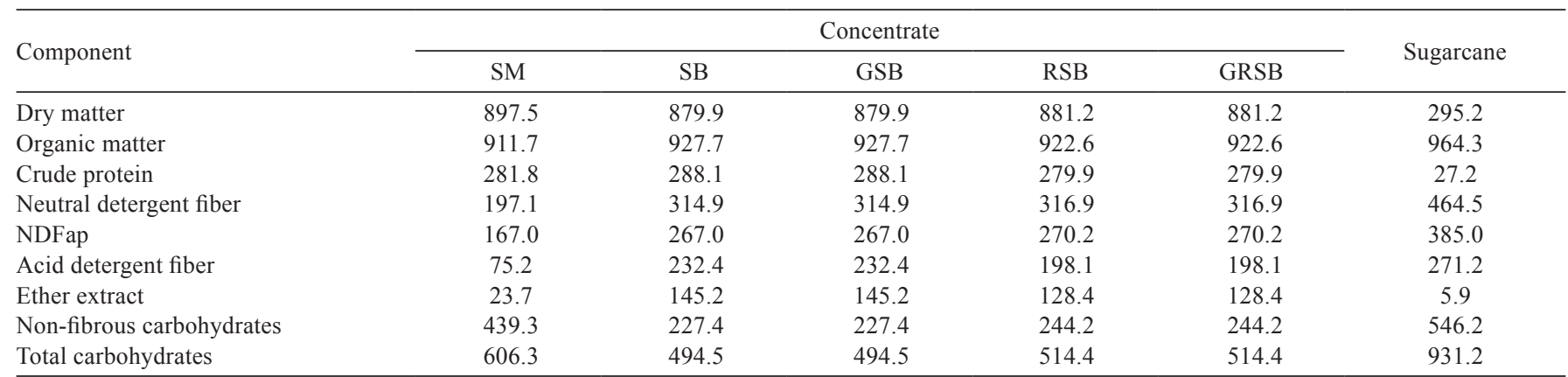

SM - soybean meal-based concentrate; SB - raw soybean-based concentrate; GSB - ground soybean-based concentrate; RSB - roasted soybean-based concentrate; GRSB - ground, roasted soybean-based concentrate.

NDFap - neutral detergent fiber corrected for the residual ash and protein. 
Table 3 - Chemical composition $(\mathrm{g} / \mathrm{kg})$ of the pasture during the experimental periods

\begin{tabular}{|c|c|c|c|c|c|}
\hline \multirow{2}{*}{ Nutrient } & \multicolumn{5}{|c|}{ Pasture } \\
\hline & $\mathrm{P} 1$ & $\mathrm{P} 2$ & P3 & $\mathrm{P} 4$ & $\mathrm{P} 5$ \\
\hline Organic matter & 917.7 & 921.2 & 931.2 & 931.0 & 935.3 \\
\hline Crude protein & 60.4 & 67.6 & 8.40 & 69.7 & 67.6 \\
\hline Neutral detergent fiber & 725.9 & 728.7 & 71.80 & 714.4 & 718.1 \\
\hline NDFap & 683.6 & 682.1 & 68.30 & 664.6 & 670.3 \\
\hline Acid detergent fiber & 420.0 & 448.4 & 433.1 & 424.3 & 426.3 \\
\hline Ether extract & 11.2 & 20.9 & 20.2 & 21.2 & 14.6 \\
\hline Non-fibrous carbohydrates & 162.5 & 150.7 & 144.1 & 175.5 & 182.8 \\
\hline Total carbohydrates & 846.1 & 832.7 & 827.1 & 840.1 & 853.1 \\
\hline
\end{tabular}

P1, P2, P3, P4 and P5 - 1st, 2nd, 3rd, 4th and 5th experimental periods, respectively. NDFap - neutral detergent fiber corrected for the residual ash and protein.

The quantities of feed supplied and orts left by each animal were recorded to estimate the intake. At the moment of feeding, all through the experimental periods, diets and orts were sampled. Samples of all ingredients used and all concentrates were also collected during the preparation of the mixtures, conditioned in plastic bags, and frozen for subsequent analyses.

The samples were dried in a forced-ventilation oven set at $55^{\circ} \mathrm{C}$ for $72 \mathrm{~h}$, and the definitive dry matter was determined in an oven at $105^{\circ} \mathrm{C}$ (DM, method 967.03; AOAC, 1998); crude protein (CP, method 2001.11; Thiex et al., 2002), crude fat (CF, method 2,003.06; Thiex et al., 2003), ash (method 942.05; AOAC, 1998), and lignin (H2SO4 72\% p/p) were analyzed according to the techniques described by method 973.18 of the AOAC (1998). Neutral detergent fiber was evaluated according to the protocols suggested by Mertens (2002). Total carbohydrates were calculated according to Sniffen et al. (1992), by the formula: TC $(\% \mathrm{DM})=100$ $-[\mathrm{CP}(\% \mathrm{DM})+\mathrm{EE}(\% \mathrm{DM})+\mathrm{MM}(\% \mathrm{DM})]$.

To calculate the excreted fecal matter, chromic oxide $\left(\mathrm{Cr}_{2} \mathrm{O}_{3}\right)$ was used as external marker. The marker was weighed $(10 \mathrm{~g})$, conditioned in filter paper and administered, via esophagus, in a single daily dose right after the morning milking, during ten days per period (Silva and Leão, 1979).

Feces were collected on the tenth, twelfth and fourteenth days of each experimental period, twice daily, at $08.00 \mathrm{~h}$ and $16.00 \mathrm{~h}$, directly from the rectum of the animals, according to the technique described by Leão (2002). Immediately after collection, the samples of feces were conditioned in plastic bags, labeled and frozen at $-10{ }^{\circ} \mathrm{C}$. Subsequently, the samples were composed on the basis of the air-dry weight, per treatment and period, and analyzed for the chromium content on an atomic absorption spectrophotometer, according to the method described by Williams et al. (1962).

For fecal output determination, the following formula was utilized $\mathrm{FO}=\mathrm{COS} / \mathrm{COF}$, in which: $\mathrm{FO}=$ daily fecal output (g DM/day); $\mathrm{COS}=$ chromic oxide supplied (g/day); and $\mathrm{COF}=$ concentration of the chromic oxide in the feces (g/g DM).

Indigestible neutral detergent fiber (iNDF) was used to determine the dry matter intake, in accordance with the technique adopted by Cochran et al. (1986). In this way, the ratio between the daily intake of the marker and its concentration in the feces was established. For the evaluation of the iNDF, the feeds and feces were ground in a $1 \mathrm{~mm}$ sieve mill and conditioned in non-woven fabric (TNT 100) bags measuring $4 \times 5 \mathrm{~cm}$, following a ratio of $20 \mathrm{mg}$ of DM per square centimeter of surface (Nocek, 1997).

Afterwards, the bags were incubated for $240 \mathrm{~h}$ (Casali et al., 2008) in the rumen of a crossbred cow (Holstein $x$ Gyr) fed a diet containing, on a DM basis, $70 \%$ of corn silage and 30\% concentrate (composed of cornmeal, soybean meal and a mineral mixture). After the incubation period, the bags were removed and washed in running water until complete clearing. Next, they were subjected to extraction with neutral detergent (Mertens, 2002), in a fiber analyzer $\left(\right.$ Ankom $200^{\circledR}$ ) and washed with warm water and acetone. After this treatment, the bags were dried in a forced-ventilation oven $\left(60^{\circ} \mathrm{C} / 72 \mathrm{~h}\right)$ and in a non-ventilated oven $\left(105^{\circ} \mathrm{C} / 45 \mathrm{~min}\right)$, conditioned in desiccators (20 bags per desiccator) and weighed (Detmann et al., 2001).

Prior to the incubation process, the bags were washed in neutral detergent according Mertens (2002) and dried similarly to the procedure described previously to obtain the tares.

Total intake was estimated by internal marker iNDF using the following formula: $\mathrm{DMI}=[(\mathrm{FO} \times \mathrm{MF})-((\mathrm{SPI}$ $\times \mathrm{MSP})+(\mathrm{SCI} \times \mathrm{IPC}) / \mathrm{MFR}]+\mathrm{MSC}+\mathrm{SCI}$, in which: $\mathrm{DMI}=$ $\mathrm{DM}$ intake $(\mathrm{kg} /$ day $) ; \mathrm{FO}=$ fecal output $(\mathrm{kg} /$ day $) ; \mathrm{MF}=$ concentration of the marker in the feces; SPI = supplement DM intake $(\mathrm{kg} /$ day); MSP $=$ concentration of the marker in the supplement; $\mathrm{SCI}=$ sugarcane intake; $\mathrm{MSC}=$ marker in the sugarcane; and MFR = concentration of the marker in the forage. 
The digestibility of the nutrients was calculated by subtracting the ingested DM by the excreted DM, divided by the ingested DM.

The non-fibrous carbohydrates (NFC) of the supplements were estimated according to Hall (2000): NFC $100-[(\%$ total CP $)+(\%$ NDFap $)+\%$ EE + \% Ash $]$.

The total digestible nutrient (TDN) contents were calculated according to the NRC (2001): TDN: DCP + $(2.25$ $\times \mathrm{DEE})+\mathrm{DNDF}+\mathrm{DNFC}-7$, in which $\mathrm{DCP}=$ digestible crude protein; $\mathrm{DEE}=$ digestible ether extract; $\mathrm{DNDF}=$ digestible neutral detergent fiber; and DNFC = digestible non-fibrous carbohydrates.

The milk was weighed on the twelfth and fourteenth days of each experimental period, whereas the milk samples were collected on the fourth day of each period. Before the collection, the milk was homogenized and, immediately after, it was stored in a container with preservative $\left(\right.$ Bronopol $^{\circledR}$ ), at the proportion of $2 / 3$ during the morning milking and $1 / 3$ in the afternoon milking; the morning samples were placed under refrigeration, and at the end of the day, they were mixed with the afternoon samples. Right after collection, milk samples were sent to the laboratory, where the milk solids were analyzed

The milk yield was corrected for $4 \%$ of fat, using the formula described in the NRC (1989): $\mathrm{kg}$ of $4 \%$ fatcorrected milk yield $=0.4(\mathrm{~kg}$ milk $)+15(\mathrm{~kg}$ milk fat $)$.

The following linear mixed statistical model was adopted (Tempelman, 2004):

$$
\mathrm{Y}_{i k l}=\mu+\alpha_{i}+\mathrm{c}_{k}+\beta_{l}+\alpha \beta_{i l}+\mathrm{e}_{i k l},
$$

in which $Y_{i k l}$ is the observation related to the variable measured in the $k$-th cow fed the $i$-th treatments during the $l$-th period. The fixed effects are the mean $(\mu)$, the treatments $\left(\alpha_{i}\right)$, the periods for the two simultaneous balanced Latin squares $\left(\beta_{l}\right)$, and the treatment $\times$ period interaction $\left(\alpha \beta_{i l}\right)$.
The random effects are cow $\left(\mathrm{c}_{k}\right)$ and the usual error term $\left(\mathrm{e}_{i k l}\right)$.

The statistical model was fitted using the PROC MIXED procedure of SAS (version 9; SAS Institute Inc., Cary, NC, USA) with restricted maximum likelihood (REML) as the estimation method. The repeated command was used with $\mathrm{c}_{k}$ as subjects. Treatments were compared by Tukey's test at $5 \%$ of probability.

\section{Results}

The intakes of dry matter, organic matter, neutral detergent fiber, total carbohydrates and total digestible nutrients were not affected $(\mathrm{P}>0.05)$ by the different processing forms of soybean in the diets (Table 4). In the average of all treatments, dry matter intake was $9.43 \mathrm{~kg}$ or $1.90 \% \mathrm{LW}$, and NDF intake was $5.03 \mathrm{~kg}$ or $1.02 \% \mathrm{LW}$.

The animals subjected to the treatments based on soybean (SB, GSB, RSB and GRSB) showed higher EE intake $(\mathrm{P}<0.05)$ in relation to the soybean meal-based diet, averaging intakes of 0.50 and 0.19 , respectively (Table 4 ).

The apparent digestibility coefficients of dry matter, crude protein, and neutral detergent fiber were not affected by the different soy processing forms $(\mathrm{P}>0.05)$, averaging $521.9,602.6$, and $360.9 \mathrm{~g} / \mathrm{kg}$, respectively (Table 5 ).

In relation to milk yield, the animals fed diets containing GRSB and SM had higher values than SB, while the other treatments had an intermediate response. The same trend was also was observed for fat-corrected milk yield, except for SM (Table 6).

Milk composition was not affected by the diets $(\mathrm{P}>0.05$; Table 6). The mean contents of protein, fat, lactose, TS and SNF were 27.5, 31.4, 45.3, 113.2, and $82.0 \mathrm{~g} / \mathrm{kg}$, respectively.

Table 4 - Average daily intakes and variations in the live weight (LW) of animals according to experimental diets and their respective coefficients of variation $(\mathrm{CV})$

\begin{tabular}{|c|c|c|c|c|c|c|}
\hline \multirow{2}{*}{ Variable } & \multicolumn{5}{|c|}{ Concentrate } & \multirow{2}{*}{$\mathrm{CV}(\%)$} \\
\hline & SM & SB & GSB & RSB & GRSB & \\
\hline \multicolumn{7}{|c|}{ Intake (kg/day) } \\
\hline Dry matter & 10.11 & 9.05 & 8.93 & 9.30 & 9.75 & 10.91 \\
\hline Organic matter & 9.36 & 8.45 & 8.33 & 8.66 & 9.08 & 10.75 \\
\hline Total digestible nutrients & 6.68 & 6.14 & 6.06 & 6.17 & 6.49 & 11.44 \\
\hline Neutral detergent fiber & 4.71 & 5.00 & 4.89 & 5.15 & 5.40 & 8.37 \\
\hline Total carbohydrates & 7.62 & 6.72 & 6.61 & 6.96 & 7.29 & 9.59 \\
\hline Crude protein & 1.55 & 1.21 & 1.21 & 1.22 & 1.29 & 21.16 \\
\hline Ether extract & $0.18 \mathrm{~b}$ & $0.51 \mathrm{a}$ & $0.51 \mathrm{a}$ & $0.47 \mathrm{a}$ & $0.50 \mathrm{a}$ & 12.78 \\
\hline \multicolumn{7}{|c|}{ Intake (g/kg of LW) } \\
\hline Dry matter & 20.4 & 18.3 & 18.0 & 18.8 & 19.7 & 110.1 \\
\hline Neutral detergent fiber & 9.5 & 10.1 & 9.9 & 10.4 & 10.9 & 83.9 \\
\hline
\end{tabular}

SM - soybean meal-based concentrate; SB - raw soybean-based concentrate; GSB - ground soybean-based concentrate; RSB - roasted soybean-based concentrate; GRSB - ground, roasted soybean-based concentrate.

Means in the row followed by different letters differ according to the Tukey test $(\mathrm{P}<0.05)$. 
Table 5 - Digestibility coefficients $(\mathrm{g} / \mathrm{kg})$ and their respective coefficients of variation $(\mathrm{CV})$ obtained for the experimental diet

\begin{tabular}{lcccccc}
\hline \multirow{2}{*}{ Digestibility coefficient } & \multicolumn{3}{c}{ Diet } & & GRSB \\
\cline { 2 - 5 } & SM & SB & GSB & RSB & 525.9 & 13.50 \\
Dry matter & 560.2 & 514.4 & 500.6 & 508.2 & 373.8 & 18.58 \\
Neutral detergent fiber & 358.7 & 348.9 & 344.9 & 378.4 & 628.8 & 10.76 \\
Crude protein & 663.6 & 556.9 & 603.8 & 560.1 & \\
\hline
\end{tabular}

SM - soybean meal-based concentrate; SB - raw soybean-based concentrate; GSB - ground soybean-based concentrate; RSB - roasted soybean-based concentrate; GRSB - ground, roasted soybean-based concentrate.

Table 6 - Production and composition of the milk from Holstein $\times$ Gyr cows fed different experimental diets

\begin{tabular}{|c|c|c|c|c|c|c|}
\hline \multirow{2}{*}{ Variable } & \multicolumn{5}{|c|}{ Diet } & \multirow{2}{*}{$\mathrm{CV}(\%)$} \\
\hline & SM & SB & GSB & RSB & GRSB & \\
\hline Milk yield (kg/day) & $7.79 \mathrm{a}$ & $6.07 \mathrm{~b}$ & $6.70 \mathrm{ab}$ & $6.98 \mathrm{ab}$ & $7.98 \mathrm{a}$ & 10.75 \\
\hline $4 \%$ fat-corrected milk yield $(\mathrm{kg} /$ day $)$ & $6.72 \mathrm{ab}$ & $5.32 \mathrm{~b}$ & $6.00 \mathrm{ab}$ & $6.35 \mathrm{ab}$ & $7.08 \mathrm{a}$ & 12.23 \\
\hline Fat $(\mathrm{g} / \mathrm{kg})$ & 31.0 & 32.0 & 31.5 & 32.4 & 31.6 & 15.72 \\
\hline Protein $(g / k g)$ & 27.9 & 28.0 & 27.2 & 26.9 & 27.3 & 4.90 \\
\hline Lactose $(\mathrm{g} / \mathrm{kg})$ & 45.5 & 44.9 & 45.1 & 45.5 & 45.4 & 1.61 \\
\hline Total solid $(\mathrm{g} / \mathrm{kg})$ & 113.7 & 111.3 & 113.5 & 114.2 & 113.1 & 4.29 \\
\hline Solids nonfat $(\mathrm{g} / \mathrm{kg})$ & 82.7 & 82.0 & 81.4 & 81.7 & 82.1 & 1.83 \\
\hline
\end{tabular}

SM - soybean meal-based concentrate; SB - raw soybean-based concentrate; GSB - ground soybean-based concentrate; RSB - roasted soybean-based concentrate; GRSB - ground, roasted soybean-based concentrate; CV - coefficient of variation.

Means in the row followed by different letters differ according to the Tukey test $(\mathrm{P}<0.05)$.

\section{Discussion}

Soy beans have approximately $39 \%$ and soybean meal approximately $2 \% \mathrm{EE}$, which favored the elevation of the lipid content of diets composed of soy beans with different treatments.

The NDF intake in the present study was below the $1.2 \%$ LW reported by Mertens (1994) as the ideal to obtain optimal DM intake. Some factors may have influenced these low intakes, such as the animals used, which were of low production and in the last third of lactation; the roughage utilized, which was brachiaria grass pasture at an advanced maturity stage; and the supplemental roughage, low-quality sugarcane. Both roughages had a high NDF content, which, coupled with the fiber digestibility of these feeds, might have negatively affected the dry matter intake because of its slow release from the rumen and slow passage through the digestive tract.

According to Oba and Allen (2003), the high fiber content determines the rumen fill, which limits dry matter intake, and consequently milk production. In the equations proposed by Mertens (1994) to estimate intake, they used animals of high production and the diets were based on ingredients containing good-quality fibers, which provided higher values than those found in the present study.

Similar results were reported by Carvalho (2001) and Corrêa (2007), who evaluated different forms of supply of soybean in a diet for high-yield cows in the first third of lactation, using the silage as roughage. Those authors did not observe differences in DM intake, although they obtained higher values: 3.03 and $3.33 \% \mathrm{LW}$, respectively.

Evaluating the inclusion of different fat sources in the diet of cows at the peak of lactation with production above $20 \mathrm{~kg} /$ day, Costa (2008) and Vargas et al. (2002) observed a decrease in DM intake when replacing diets based on soybean meal by soy beans.

Diets based on soybean (SB, GSB, RSB, and GRSB) showed an average content of $4.62 \% \mathrm{EE}$, whereas the diet with soybean meal showed $1.99 \%$ EE, which explains the higher ether extract intake of the animals fed the diets based on soy beans, although the dry matter intake did not vary between treatments.

The lipid content of the diet may affect the digestibility, creating a physical barrier that surrounds the fiber and hindering the attack of the rumen microflora to the particles. Besides, when supplied at high amounts, usually above $7 \%$, fat may be toxic to the rumen microorganisms, especially when supplied at a large proportion of unsaturated fatty acids, sometimes being toxic to the ruminal microorganisms (Kozloski et al., 2002).

The observed digestibility values for all variables (Table 5) are below those reported in the literature (Guidi et al., 2007; Silva et al., 2009), which is explained by the use of brachiaria grass as roughage source at an advanced maturity stage, associated with the sugarcane, which are two roughage feeds of low quality, with elevated iNDF content. Moreover, the low amount of NFC decreased the digestibility of nutrients (Table 5). Another factor that could 
cause reduced digestibility is inclusion of fats; however, the EE levels remained within the recommended range in the literature, and therefore do not affect the fiber digestibility.

The others similar results, although higher, were observed by Corrêa (2007), who did not report difference between the digestibility of DM, CP, and NDF when replacing soybean meal by soy in different forms of processing in diets for high-yield cows fed corn silage as roughage feed, with mean values of $67.16,71.15$, and $53.40 \%$, respectively.

Supplying soy beans in diets for lactating cows may affect both production and composition of the milk due to the elevated fat content of this ingredient. The diets used in this study presented a lower EE content than the maximum inclusion level suggested by Palmquist and Mattos (2006) (5 to $7 \%$ of EE in the diet, depending on the animal category and production), without impairing the use of the feeds by cattle, since the diets composed of soy beans showed a higher EE $(4.62 \%)$ than the diet containing soybean meal $(1.99 \%)$.

It can be assumed that the degradability of the crude protein from the different sources caused differences in milk yield, with GRSB better in relation to SB, with different uptakes and amino acid profiles that reached the mammary gland. Similar results were observed by Mora et al. (1996), who found a $17.7 \%$ decrease in $4 \%$ fat-corrected milk from cows fed a diet containing $45 \%$ soy beans in the concentrate as compared with a diet with soybean meal. Rabelo et al. (1996) also reported reduction in 4\% fat-corrected milk yield when they added soy beans to the diet.

Regarding milk yield, Carvalho (2001) worked with replacement of raw and roasted soy beans in a commercial concentrate and a soybean meal-based concentrate and did not observe differences in corrected milk yield. Likewise, working with replacement of soybean meal by raw soy beans, roasted soy beans and soybean meal $+5 \%$ urea in the diet of high-yield cows, Corrêa (2007) also did not observe differences in milk production. Working with inclusion of fats (soy beans and soybean oil) replacing soybean meal in diets for lactating cows, Vargas et al. (2002) did not observe differences in corrected milk yield.

A possible explanation for this absence of effect on the composition of the milk would be the similarity of the composition of experimental diets associated with the low production and the advanced lactation period of the animals utilized.

Among the milk components, the fat content is the easiest to be altered through the diet. The milk solids nonfat, however, are the least likely to change according to the feeding management. Lactose practically does not change according to the diet, because it is osmotically active, so the quantity of milk will be higher as the lactose content in the secreting epithelial cells is increased (Nunes, 2004).

The results obtained in the present study regarding the composition of milk agree with those observed by Santos et al. (2001), Barnabé et al. (2007), and Corrêa (2007), who evaluated soy in different forms in diets for lactating cows and also did not obtain significant effects. On the other hand, Vilela et al. (2003) observed an increase in the milk fat content when they replaced soybean meal by roasted soy beans in diets for high-yield cows. According to these authors, this accrual is because the process of roasting whole soy beans increases the digestibility of the fatty acids in the gastrointestinal tract of lactating cows and the use of roasted whole soybean elevated the polyunsaturated fatty acid content of the milk fat as compared with the animals which received soybean meal.

\section{Conclusions}

Soybean meal can be replaced by ground soy bean or roasted soy bean - ground or whole - in diets for lowyield cows on a Brachiaria decumbens pasture with no detrimental effects on the production and composition of milk. Thus, these alternative raw materials can be chosen whenever their inclusion results in lower feeding costs.

\section{References}

AOAC - Association of Official Analytical Chemists. 1998. Official methods of analysis. 16th ed., 4th rev. AOAC International, Gaithersburg.

Barnabé, E. C.; Santos, F. A. P. and Machado, C. M. 2007. Fontes protéicas e energéticas com diferentes degradabilidades ruminais para vacas em lactação. Acta Scientiarum Animal Sciences 29:209-216.

Carvalho, N. M. 2001. Utilização do grão tostado de soja (Glycine max. (L) Merril) na alimentação de vacas em lactação. Tese (D.Sc.). Universidade Federal do Rio Grande do Sul, Porto Alegre.

Casali, A. O.; Detmann, E.; Valadares Filho, S. C.; Pereira, J. C.; Henriques, L. T.; Freitas, S. G. and Paulino, M. F. 2008. Influência do tempo de incubação e do tamanho de partículas sobre os teores de compostos indigestíveis em alimentos e fezes bovinas obtidos por procedimentos in situ. Revista Brasileira de Zootecnia 30:335-342.

Cochran, R. C.; Adams, D. C.; Wallace, J. D. and Galyean, M. L. 1986. Predicting digestibility of different diets with internal markers: evaluation of four potential markers. Journal of Animal Science 63:1476-1483.

Corrêa, A. M. V. 2007. Utilização da soja em diferentes formas na alimentação de vacas leiteiras. Tese (D.Sc.). Universidade Federal de Viçosa, Viçosa, MG.

Costa, M. G. 2008. Rações com diferentes fontes de gordura para vacas em lactação. Tese (D.Sc.). Universidade Federal de Viçosa, Viçosa, MG. 
Detmann, E.; Paulino, M. F.; Zervoudakis, J. T.; Valadares Filho, S. C.; Euclydes, R. F.; Lana, R. P. and Queiroz, D. S. 2001. Cromo e indicadores internos na determinação do consumo de novilhos mestiços suplementados a pasto. Revista Brasileira de Zootecnia 30:1600-1609.

Guidi, M. T.; Santos, F. A. P.; Bittar, C. M. M.; Pires, A. V.; Menezes Jr., M. P. and Imaizumi, H. 2007. Efeito de fontes e teores de proteína sobre a digestibilidade de nutrientes e desempenho de vacas em lactação. Acta Scientiarum. Animal Sciences 29:325-331.

Hall, M. B. 2000. Neutral detergent-soluble carbohydrates, nutritional relevance and analysis. A laboratory manual. Bulletin 339. University of Florida, Florida.

Kozloski, D. N. 2002. Bioquímica dos ruminantes. Editora UFSM, Santa Maria.

Leão, M. I. 2002. Metodologias de coletas de digestas omasal e abomasal em novilhos submetidos a três níveis de ingestão: consumo, digestibilidade e produção microbiana. Tese (D.Sc.). Universidade Federal de Belo Horizonte, Belo Horizonte, MG.

Mertens, D. R. 1994. Regulation of forage intake. p.450-493. In: Forage quality, evaluation and utilization. Fahey Jr, G. C., ed. American Society of Agronomy, Wisconsin.

Mertens, D. R. 2002. Gravimetric determination of amylasetreated neutral detergent fiber in feeds with refluxing in beaker or crucibles: collaborative study. Journal of AOAC International 85:1217-1240.

Mora, P. J. G.; Leão, M. I.; Valadares Filho, S. C.; Coelho da Silva, J. F.; Malafaia, P. A. M. and Vieira, R. A. M. 1996. Grão de soja em rações para vacas lactantes: Consumo dos nutrientes, produção e composição do leite. Revista da Sociedade Brasileira de Zootecnia 25:369-381.

NRC - National Research Council. 1989. Nutrient requeriments of dairy cattle. 6th ed. National Academy of Science, Washington, D.C.

NRC - National Research Council. 2001. Nutrient requirements of dairy cattle. 7th rev. ed. National Academy Press, Washington D.C.

Nocek, J. E. 1997. In situ and other methods to estimate ruminal protein and energy digestibility: a review. p.197-240. In: Digestibilidade em ruminantes. Teixeira, J. C., ed. FAEPE, Lavras.

Nunes, A. F. 2004. Leite mecanismo de produção. Federação Nacional das Cooperativas de Produtores de Leite, FENALAC, Vila do Conde.

Oba, M. and Allen, M. S. 2003. Effects of corn grain gain conservation method on feeding behavior and productivity of lactating cows at two dietary starch concentrations. Journal of Dairy Science 86:174-183.

Palmquist, D. L. and Mattos, W. R. S. 2006. Metabolismo de lipídeos. p.287-310. In: Nutrição de ruminantes. Berchielli, T. T., ed. FUNEP, Jaboticabal.

Rabello; T. G.; Valadares Filho, S. C.; Coelho da Silva, J. F.; Leão, M. I.; Cecon, P. R. and Castro, A. C. G. 1996. Grão de soja moído na alimentação de vacas em lactação. I. Consumos, produção e composição do leite. Revista da Sociedade Brasileira de Zootecnia 25:345-356.

Santos, F. L.; Lana, R. P.; Silva, M. T. C.; Brandão, S. C. C. and Vargas, L. H. 2001. Produção e composição do leite de vacas submetidas a dietas contendo diferentes níveis e formas de suplementação de lipídios. Revista Brasileira de Zootecnia 30:1376-1380.

Silva, C. V.; Lana, R. P.; Campos, J. M. S.; Queiroz, A. C.; Leão, M. I. and Abreu, D. C. 2009. Consumo, digestibilidade aparente dos nutrientes e desempenho de vacas leiteiras em pastejo com dietas com diversos níveis de concentrado e proteína bruta. Revista Brasileira de Zootecnia 38:1372-1380.

Silva, J. F. C. and Leão, M. I. 1979. Fundamentos de nutrição dos ruminantes. Livroceres, Piracicaba.

Sniffen, C. J.; O'Connor, J. D.; Van Soest, P. J.; Fox, D. G. and Russell, J. B. 1992. A net carbohydrate and protein system for evaluation cattle diets. II. Carbohydrate and protein availability. Journal Animal Science 70:3562-3577.

Sollengerger, L. E. and Cherney, D. J. R. 1995. Evaluating forage production and quality. p.97-110. In: The science grassland agriculture. Iowa State University Press, Ames.

Tempelman, R. J. 2004. Experimental design and statistical methods for classical and bioequivalence hypothesis testing with an application to dairy nutrition studies. Journal of Animal Science $82: 162-172$

Thiex, N. J.; Manson, H.; Anderson, S. and Persson, J. A. 2002. Determination of crude protein in animal feed, forage, grain, and oilseeds by using block digestion with a copper catalyst and steam distillation into boric acid: collaborative study. Journal of AOAC International 85:309-317.

Thiex, N. J.; Anderson, S. and Gildemeister, B. 2003. Crude fat, hexanes extraction, in feed, cereal grain, and forage (Randall/ soxtec/submersion method): collaborative study. Journal of AOAC International 86:899-908.

Tice, E. M.; Eastridge, M. L. and Firkins, J. L. 1993. Raw soybeans and roasted soybeans of different particle sizes. 1. Digestibility and utilization by lactating cows. Journal of Dairy Science $76: 224-235$.

Vargas, L. H.; Lana, R. P. and Jham, G. N. 2002. Adição de lipídios na dieta de vacas leiteiras: parâmetros fermentativos ruminais, produção e composição do leite. Revista Brasileira de Zootecnia 31:522-529.

Vilela, D.; Matos, L. L.; Alvim, M. J. and Matiolli, J. B. 2003. Utilização de soja integral tostada na dieta de vacas em lactação, em pastagem de Coastcross (Cynodon dactylon, L. Pers.). Revista Brasileira de Zootecnia 32:1243-1249.

Willians, C. H.; David, D. J. and Ilsmaa, O. 1962. The determination of chromic oxide in feces samples by atomic absorption spectrophotometers. Journal Agriculture Science 59:381-385. 